\title{
Accounting Students' and Employers' Perceptions on Employability Skills in the SEE Country
}

\author{
Atanasko Atanasovski - Marina Trpeska \\ - Zorica Bozinovska Lazarevska *
}

\begin{abstract}
:
Accounting education at the university level in developing SEE countries has often been criticised for the inability to develop essential skills of graduates necessary for a career in professional accountancy in the 21st century. Our research study presents the results of a survey among students enrolled to an accounting degree program and employers for their perceived importance of a wide range of generic and technical skills for successful entrance to the profession. The study also investigated perceived effectiveness of the university accounting education to develop important skills at an appropriate level. The results indicated agreement between the two respondent groups in respect of the greater importance of generic skills, where students gave more weight to personal skills of time management, good presentation and characteristics of self-confidence, motivation and selfpromotion. Employers valued more oral communication, knowledge of foreign languages, ethical attitude and credibility and commitment to life-long learning. The employers and students agreed that education process and program need improvements in order to allow for better development of technical and generic skills among successful graduates.
\end{abstract}

Key words: Generic Skills; Students Employability; Expectation Gap; Students' Perceptions.

JEL classification: J24, M41.

\section{Introduction}

It has been argued that the transition of young people from school to work has become longer, complex and more difficult. Arguably or not, there are more concerns among policy makers and social partners across Europe for the gap

\footnotetext{
Atanasko Atanasovski; University Ss Cyril and Methodius in Skopje, Faculty of Economics, Goce Delchev 9V, 1000 Skopje, Macedonia,<atanasko@eccf.ukim.edu.mk>.

Marina Trpeska; University Ss Cyril and Methodius in Skopje, Faculty of Economics, Goce Delchev 9V, 1000 Skopje, Macedonia,<marinas@eccf.ukim.edu.mk>.

Zorica Bozinovska Lazarevska; University Ss Cyril and Methodius in Skopje, Faculty of Economics,Goce Delchev 9V, 1000 Skopje, Macedonia, <zoricab@eccf.ukim.edu.mk>.

The article is processed as an output of a research project "Study of views and perceptions of students, employers and academic community for contemporary skills and knowledge in the accounting professions" financed by the University Ss. Cyril and Methodius in Skopje, decision no. 02-560 from 30.06.2017.
} 
Atanasovski, A. - Trpeska, M. - Bozinovska Lazarevska, Z.: Accounting Students' and Employers' Perceptions on Employability Skills in the SEE Country.

between the skills possessed by workers and needs of the labour market. The gap between skills actually possessed by individuals and skills needed for the workplace threatens societies and their capacity to achieve sustainable growth. Nonetheless, educators and policy makers in Europe recognise the significance of higher education for the development of modern knowledge-based societies and economies, where universities will produce highly skilled and mobile workers who can deal with dynamic and complex needs of a modern workplace (Andrews and Higson, 2008).

Albrecht and Sack (2000) highlighted the technological innovation, trend towards global business environment and concentration of power in certain investors as major developments that will influence accountants. These trends strengthened the importance of generic skills in addition to technical skills traditionally taught and expected from accountants. However, the accounting education was heavily criticised for failing to address the skill requirements in today's dynamic business environment. A number of studies, majority of them done in countries with welldeveloped education systems such as US, UK or Australia, have provided evidence of inappropriate quality of accounting graduates and perceptions by professionals for the accounting education being outdated or irrelevant for the market (Albrecht and Sack, 2000; De Lange, Jackling, and Gut, 2006; Gabbin, 2002).

Many studies investigating the role of skills in accounting education have been focused on the expectation gap between what employers or recruiters think as necessary for the accounting career and what students think is required for the workplace (Hassall, Joyce, Montano, and Anes, 2003; Jackling and De Lange, 2009; Leveson, 2000; Webb and Chaffer, 2016; Wells, Gerbic, Kranenburg, and Bygrave, 2009). A gap in skills has been identified that points to accounting graduates lacking, amongst other things, communication and problem-solving skills that are expected by the accounting profession based on the surveys of both recent accounting graduates and accounting employers. The accounting education model needs to focus on developing a set of skills in analytical and critical thinking, technology, communication and teamwork for graduates to be prepared to pursue successful careers in the accounting profession.

The purpose of this study is to contrast the perceptions and views of the two interested parties for accounting education in Macedonia, the accounting students and employers (from professional accounting and auditing firms) in respect of skills and knowledge that must be possessed by accounting graduates in order to increase their employability and workplace readiness. Secondly, the study aims to evaluate the quality of a recognised undergraduate accounting program in order to determine if it allows for relevant skills and knowledge to be obtained as per employers' and students' perceptions. We focused our investigation on identifying 
major shifts in the most important skills and knowledge sets as per employers' expectations and analyse the skills' gap left by the formal education system.

Through the use of questionnaire survey, this research examines the perceptions among students of an accounting undergraduate program and a wide group of employers of accounting graduates on the importance of 39 identified generic and subject-specific technical skills. Possession of these skills among successful graduates of an accounting undergraduate program has also been surveyed within the two focus groups.

In particular, the research questions were:

- What set of skills and knowledge within the Macedonian business environment needs to be adopted by young entrants in the accounting profession as perceived by accounting students and employers?

- Is there a gap between students' and employers' perceptions in respect of the needed skills and knowledge?

- Is the selected accounting undergraduate program appropriately designed and executed by the accounting academia to provide for the necessary skills and knowledge, as per students' and employers' perceptions?

The rest of the paper is structured as follows: Section 2 reviews the literature on skills appropriate for accounting education, both at the university and professional setting, and identifies which skills are cited as the most important for an appropriate transit from school to modern environment. Section 3 explains the methodology of the research study, composition of the survey instrument and describes the groups surveyed in the study. A discussion on the research findings is presented in Section 4, followed by concluding remarks in the final section of this paper.

\section{Literature Review}

The contemporary business environment and landscape for consultancy services is changing rapidly, inherently requiring accountants to have broadly-based education that will develop skills and knowledge of accounting information systems in addition to knowledge regarding the role of the accounting function within a modern organisation. As early as 1998, American Institute of CPAs surveyed its members and concluded that the profession needs to provide services outside the traditional accounting and auditing in order to be competitive. Successful provision of such client value services is largely based on professional judgement, where the accountants need to develop further their communication and leadership skills, strategic thinking and client focus (AICPA, 1998). Similarly, the Institute of Chartered Accountants of Australia in a study based on interviews 
and surveys identified that the accounting profession needs to complete a major shift from information-based to knowledge-based services (ICAA, 2001).

Many studies have highlighted the fact that increased reliance on IT technology could replace a lot of work and specific tasks performed by traditionally trained accountants and auditors (Albrecht and Sack, 2000; Crawford, Helliar, and Monk, 2011). These advancements in IT technology will require accounting and assurance professionals to develop broader skills related to public practice, such as analytical reasoning, interpersonal, negotiating and communication skills, marketing skills, as well as broader business knowledge. Howieson (2003) argues that accountants in order to stay competitive need to acquire specialist knowledge in a specific industry but they will also have to possess broad generic skills in order to apply specialist knowledge within the "big picture" context of their organisation and its strategy. According to Bunney et al. (2015), generic skills discourse is imperative for the new knowledge economy and transcends disciplinary boundaries and international borders. The new knowledge economy emerging as a result of technological advancements needs graduates with flexible mindsets and transferable generic skills, capable of innovating and adapting to dynamic work environment. The authors propose a model for integration and contextualisation of generic skills development in all disciplines of accounting programs from elementary to final years.

Aside individual research studies, relevant skills for accounting education at the university and professional level have been developed by many national regulatory and professional bodies. The UK Quality Assurance Agency facilitates development of the subject benchmark statement for accounting that is a part of the UK Quality Code for Higher Education (QAA, 2016). The accounting benchmark statement identifies subject-specific knowledge and skills and cognitive abilities and generic skills relevant for developing higher education programs in the UK. The subject-specific skills are concentrated on obtaining technical knowledge at the elementary level concerning main and alternative accounting practices related to financial accounting, management accounting, auditing and taxation. Students need to develop technical skills to analyse, record and summarise transactions and economic events, skills to produce and analyse financial statements, analyse operations and make projections for the business. Generic skills and abilities are important as well, including the use of IT technologies, communication of relevant information, critical evaluation of data and solving unstructured problems. Students need to obtain numeracy skills, effectively work in groups and be prepared for independent and self-managed learning. These skills developed as a benchmark for higher education institutions are noticeably comparable with the relevant skills and competencies defined by IFAC's International Accounting Education Standards. IAESB develops these 
education standards in order to provide guidance to professional accountancy bodies worldwide when developing professional education programs for aspiring professional accountants. In addition, universities can refer to international education standards when designing educational programs and course curricula.

Essentially the same skills have been covered in the literature, although grouped differently by different authors. Gammi, Gammie and Cargill (2002) highlight several generic skills that need to be incorporated and taught in a separate business enterprise course module. As important, they highlight CV writing, interview skills, job search, time management, practical research, presentation skills, teamwork, business use of IT, career planning, etc. Jones (2014) argues that defining generic skills is important for undergraduate accounting programs; however it does not provide the full picture of what is expected from and required by accounting graduates. The demonstration of skills, attributes, attitudes and behaviours taken together enable the graduate to establish his or her professional credibility with colleagues and clients and advance in his or her professional career. The authors suggests that students need awareness of what is required to establish professional credibility and need to be provided an opportunity during their studies to develop this ability through simulated tasks in a professional environment. Webb and Chaffer (2016) have investigated whether important generic skills are being appropriately developed within university courses in the UK and managed to identify generic skills considered important by employers and being perceived as insufficiently developed at universities by accounting graduates. The group of underdeveloped skills included oral communication, commitment to life-long learning, ethical awareness, vision and resilience.

Wells et al. (2009) investigated in New Zealand what capabilities are important for successful career in the professional practice, the extent to which universities are focused on developing these skills and the ways to improve the content, delivery and assessment of accounting programs. The authors investigated 40 skills categorised as personal, interpersonal and intellectual capabilities, professionspecific skills and knowledge and generic skills. According to the perceptions of employed graduates, among the 15 top rated capabilities 14 are related to personal, interpersonal and intellectual skills and only one is concerned with technical expertise specific to the profession of an accountant.

Many research studies have investigated the employers' perceptions about desired attributes of accounting graduates. De Lange et al. (2006) surveyed graduates from two universities in Australia to determine their perceptions regarding skills to be found among graduates pursuing accounting career and the emphasis on developing such skills through accounting degree programs. The respondents identified lack of focus in applied learning methods to develop important generic skills, particularly interpersonal, oral communication and IT and computing skills. 
Kavanagh and Drennan (2008) diagnosed similar expectations between students of accounting programs and employers in terms of analytical and problem-solving skills, oral and written communication skills, teamwork and continuous learning. However, employers rated oral communication skills as more important than written communication skills, which are usually more cultivated at university accounting programs. Employers rated as very important business awareness and real-life experience, ethics and professionalism and basic accounting. Jackling and De Lange (2009) concluded similarly in their research study of students and employers the perceptions in respect of technical and generic skills important for professional accounting career. According to their findings, employers rated generic skills above technical skills when arriving at the employment decision. The most desired generic skills included teamwork, leadership and verbal communication, while key accounting skills and accounting problem analysis were considered as the most important technical skills.

$\mathrm{Yu}$, Churyk and Chang (2013) evaluated perceptions of interns, alumni and employers in respect of how well an undergraduate accounting program in a large public university in the US was developing career-essential skills. Interns perceived weaknesses in their skills of database use and technical competence in financial reporting. Alumni reported perceived weaknesses in database use, oral communication, technology skills and problem solving. However, employers considered interns lack sufficient skills in communication and spreadsheets use, but assessed interns as well prepared in ethics. Tempone et al. (2012) investigated the requirements by accounting employers from different sectors in Australia from accounting graduates in terms of generic attributes and skills. The authors concluded that communication, teamwork and self-management skills are the most critical for graduates, though employers from different sectors have different demands on universities to delivery work-ready graduates.

As a way to better analyse the gap identified in prior research studies, Bui and Porter (2010) develop a comprehensive framework in order to explain the gap between expected skills among graduates by the profession and perceived possession of such skills. The authors explained the structure of the gap as being comprised of difference in expectations by employers and educators regarding competencies that should be acquired (expectation gap), constraints in effectiveness of accounting education (constraints gap) and differences in competencies educators expect to be acquired by graduates and those that employers believe graduates actually possess (performance gap). An accounting program of a university in New Zealand was used as a case study to ascertain the validity of hypothesised structure of the gap, where a small sample of students, educators and employers where interviewed for their expectations regarding the skills that graduates need to possess. Employers expected from graduates 
possession of sound knowledge of accounting principles and concepts, basic understanding of business, communication, teamwork and interpersonal skills. Differing from employers, educators believed that their purpose is to extend students' intellectual abilities such as thinking skills, followed by strong technical accounting knowledge and skills. According to the study, inadequate resources, large class sizes, entry requirements and university tenure and promotion policies that motivate more research than teaching activities are institutional factors that add to the constraints gap.

Following the results of earlier empirical studies into the investigations of relevant skills and mapping these skills with academic and professional education competencies frameworks, we have gathered and classified 39 separable technical and generic skills. Our study captures views of the students and employers with the purpose of identifying gaps in perceptions in respect of importance of skills and teaching effectiveness in the skills' development process at a university.

\section{Research Methodology}

The research methodology was based on a survey instrument, a questionnaire created and distributed online both to the students and employers. The investigative part of the questionnaire had 2 sections in respect of 13 technical skills and 26 generic skills. Section 1 asked students and employers to rate on the 5-point Likert scale the importance of each technical and generic skill (1 - not important; 5 - very important), while section 2 required students and employers to rate their perceptions how well the skills are being developed through successful completion of courses of the accounting program (scores ranging from 1 - not achieved to 5 - substantially achieved). Also, based on the students' and employers' answers, a rank list is developed with top 10 ranked technical and generic skills.

\subsection{Sample}

Valid questionnaires were completed by 68 undergraduate students from the third and fourth year of studies on the Accounting and Auditing Department, giving a response rate of $27.3 \%$. The sample was evenly distributed considering the average grade of surveyed students. In respect of surveyed students' practical experience, the vast majority of respondents $(40 \%)$ have indicated a minimum one month practical experience in a professional accounting firm and $26 \%$ of the respondents were students with no practical experience related to the public practice accounting and/or auditing. 19\% of the students have practical experience in companies outside the accounting and auditing profession. Regarding the students' career, $69 \%$ of the students answered that they would like to have a professional career in an accounting and/or auditing company while 13\% 
Atanasovski, A. - Trpeska, M. - Bozinovska Lazarevska, Z.: Accounting Students' and Employers' Perceptions on Employability Skills in the SEE Country.

answered that they plan to work in financial institutions, $11 \%$ in a different private sector company and the remainder wanted to work in the public sector.

On the employers' side, more than 30 entities were contacted to complete the questionnaire. The employers' questionnaire was controlled for survey participants that had experience in interviewing and recommended or decided on recruiting candidates for accounting and audit-related posts in the business and professional practice. In summary, 57 employers participated in the survey, $35.6 \%$ of them were from audit firms, $30.5 \%$ were internal auditors, $15.3 \%$ of the respondents were from human resource departments, $10.2 \%$ were from accounting and tax consulting firms, $8.5 \%$ were top managers, and $5.1 \%$ were from finance departments within companies. This organisation of the research enabled us to have two independent samples in order to compare the perceptions of employers and students.

\section{Results and Discussion}

First, we have compared the mean values and analysed the results for students' perceptions of technical and generic skills' importance for their employment against their views of a sufficient accomplishment of these skills through the completed courses of the undergraduate degree program. Table 1 shows the means and differences in students' responses in respect of skill importance and skill achievement.

\section{Tab. 1 Students' ratings of technical and generic skills - importance vs.} achieved

\begin{tabular}{lcccc}
\hline Technical and Generic Skills & Importance & Achieved & Diff. & Sig. \\
\hline Technical Skills & & & & \\
\hline Financial Accounting & 4.53 & 3.57 & 0.96 & 0.00 \\
Management Accounting & 4.37 & 3.47 & 0.90 & 0.00 \\
Auditing & 4.44 & 3.10 & 1.34 & 0.00 \\
Business Law & 4.03 & 2.79 & 1.23 & 0.00 \\
Taxation & 4.41 & 2.96 & 1.46 & 0.00 \\
Finance and Financial Management & 4.31 & 3.57 & 0.74 & 0.00 \\
Corporate Governance, Risk Management and & 3.88 & 2.90 & 0.99 & 0.00 \\
Internal Controls & & & & \\
Business Environment, Business Strategies and & 3.85 & 3.29 & 0.56 & 0.00 \\
Management & & & & \\
Numerical Skills (Math and Stat) & 4.16 & 3.81 & 0.35 & 0.06 \\
MS Office & 4.57 & 3.62 & 0.96 & 0.00 \\
ICT (information and Communication Technologies) & 4.32 & 2.78 & 1.54 & 0.00 \\
Interdisciplinary of Accounting & 4.13 & 3.19 & 0.94 & 0.00 \\
Accounting Software & 4.63 & 2.63 & 2.00 & 0.00 \\
\hline
\end{tabular}




\begin{tabular}{lrrrr}
\hline Technical and Generic Skills & Importance & Achieved & Diff. & Sig. \\
\hline Generic Skills & & & & \\
\hline Analysing Information & 4.40 & 3.38 & 1.02 & 0.00 \\
Decision Making & 4.53 & 3.35 & 1.18 & 0.00 \\
Critical Thinking & 4.34 & 3.41 & 0.93 & 0.00 \\
Problem Solving & 4.71 & 3.53 & 1.18 & 0.00 \\
Creative Thinking & 4.34 & 3.26 & 1.07 & 0.00 \\
Written Communication & 4.46 & 3.37 & 1.09 & 0.00 \\
Oral Communication & 4.59 & 3.62 & 0.97 & 0.00 \\
Effective Listening & 4.43 & 3.88 & 0.54 & 0.00 \\
Presentation Skills & 4.38 & 3.38 & 1.00 & 0.00 \\
Foreign Language & 4.66 & 3.93 & 0.74 & 0.00 \\
Good presentation at Interview & 4.68 & 3.26 & 1.41 & 0.00 \\
Personal Characteristics & 4.75 & 4.12 & 0.63 & 0.00 \\
Leadership & 4.57 & 3.57 & 1.00 & 0.00 \\
Self-initiative & 4.31 & 3.50 & 0.81 & 0.00 \\
Ethical & 4.49 & 4.00 & 0.49 & 0.00 \\
Independent & 4.31 & 3.65 & 0.66 & 0.00 \\
Personal Success & 4.59 & 4.19 & 0.40 & 0.01 \\
Time Management & 4.68 & 4.04 & 0.63 & 0.00 \\
Life Learning & 4.43 & 3.72 & 0.71 & 0.00 \\
Flexibility & 4.47 & 3.72 & 0.75 & 0.00 \\
Negotiation & 4.44 & 3.44 & 1.00 & 0.00 \\
Company Promotion & 4.19 & 2.96 & 1.24 & 0.00 \\
Group Dynamics & 4.07 & 3.41 & 0.66 & 0.00 \\
Teamwork & 4.66 & 4.09 & 0.57 & 0.00 \\
Credibility & 4.62 & 4.10 & 0.52 & 0.00 \\
Interethnic Culture & 4.46 & 4.15 & 0.31 & 0.05 \\
\hline Source: Survey & & &
\end{tabular}

Source: Survey instrument responses, authorial computation.

The interesting finding is that students consistently rated with high importance almost all technical and generic skills but they do not think that they acquire sufficient knowledge for the same respective skills during their studies. Students perceived personal skills of time management and personal characteristics of selfconfidence, personal motivation and desire for self-promotion, good presentation at interviews as the most important for their future workplace. Interpersonal generic skills of teamwork were ranked with high importance, however, on average students gave generic skills higher importance scores then technical skills. These findings regarding the higher importance of generic skills are consistent with the findings of many international studies (Hassall et al., 2003; Jackling and De Lange, 2009; Kavanagh and Drennan, 2008; Wells et al., 2009). Students perceived acquired skills through their education program being significantly 
Atanasovski, A. - Trpeska, M. - Bozinovska Lazarevska, Z.: Accounting Students' and Employers' Perceptions on Employability Skills in the SEE Country.

lower compared to the rated importance of these skills for their employment. The results show that relevant skills are being moderately developed, some even less than satisfactorily developed. It can be concluded that technical skills related to computers such as ICT and accounting software as well as knowledge in areas such as business law and taxation are not well developed through the education process. This finding is also consistent with the findings of many international studies (De Lange et al., 2006; Gammie et al., 2002; Jackling and De Lange, 2009; Mohamed and Lashine, 2003; Wells et al., 2009).

The resulting analysis of responses of employers involved in the recruitment of accounting graduates showed that technical skills of acquaintance with MS Office and knowledge in financial accounting were the most important (Table 2). However, generic skills of graduates on average were considered as more important for their accounting-related job place. Employers gave personal and interpersonal skills of oral communication, knowledge of foreign languages, ethical attitude and credibility, commitment to life-long learning the highest ranks for importance. Our findings were similar to the findings of other researchers of employers' perceptions of skills published internationally. Jones (2014) highlighted the importance of graduates' ability to establish his or her professional credibility among colleagues and clients, which requires a range of personal attributes, attitudes and behaviours. Similarly, Jackling and De Lange (2009) found that employers value generic skills as more important for employability of graduates that technical skills, particularly oral and written communication skills and personal skills.

\section{Tab. 2 Employers' ratings of technical and generic skills - importance vs. acquired}

\begin{tabular}{lcccc}
\hline Technical and Generic Skills & Importance & Achieved & Diff. & Sig. \\
\hline Technical Skills & & & & \\
\hline Financial Accounting & 4.54 & 3.19 & 1.35 & 0.00 \\
Management Accounting & 4.31 & 3.19 & 1.13 & 0.00 \\
Auditing & 4.44 & 3.28 & 1.17 & 0.00 \\
Business Law & 4.13 & 2.85 & 1.28 & 0.00 \\
Taxation & 4.15 & 2.61 & 1.54 & 0.00 \\
Finance and Financial Management & 4.02 & 3.15 & 0.87 & 0.00 \\
Corporate Governance, Risk Management and & 4.26 & 3.00 & 1.26 & 0.00 \\
Internal Controls & & & & \\
Business Environment, Business Strategies and & 4.04 & 2.93 & 1.11 & 0.00 \\
Management & & 3.33 & 0.85 & 0.00 \\
Numerical Skills (Math and Stat) & 4.19 & 3.69 & 1.06 & 0.00 \\
MS Office & 4.74 & 3.15 & 1.24 & 0.00 \\
ICT (information and Communication Technologies) & 4.39 & & & \\
\hline
\end{tabular}




\begin{tabular}{|c|c|c|c|c|}
\hline Technical and Generic Skills & Importance & Achieved & Diff. & Sig. \\
\hline \multicolumn{5}{|l|}{ Generic Skills } \\
\hline Interdisciplinary of Accounting & 4.22 & 3.00 & 1.22 & 0.00 \\
\hline Accounting Software & 3.50 & 2.48 & 1.02 & 0.00 \\
\hline \multicolumn{5}{|l|}{ Generic Skills } \\
\hline Analysing Information & 4.59 & 3.30 & 1.30 & 0.00 \\
\hline Decision Making & 4.50 & 3.04 & 1.46 & 0.00 \\
\hline Critical Thinking & 4.61 & 3.19 & 1.43 & 0.00 \\
\hline Problem Solving & 4.54 & 3.13 & 1.41 & 0.00 \\
\hline Creative Thinking & 4.30 & 3.00 & 1.30 & 0.00 \\
\hline Written Communication & 4.44 & 3.26 & 1.19 & 0.00 \\
\hline Oral Communication & 4.72 & 3.19 & 1.54 & 0.00 \\
\hline Effective Listening & 4.65 & 3.20 & 1.44 & 0.00 \\
\hline Presentation Skills & 4.26 & 3.09 & 1.17 & 0.00 \\
\hline Foreign Language & 4.74 & 3.74 & 1.00 & 0.00 \\
\hline Good presentation at Interview & 4.35 & 3.52 & 0.83 & 0.00 \\
\hline Personal Characteristics & 4.46 & 3.48 & 0.98 & 0.00 \\
\hline Leadership & 4.13 & 3.11 & 1.02 & 0.00 \\
\hline Self-initiative & 4.54 & 3.19 & 1.35 & 0.00 \\
\hline Ethical & 4.76 & 3.65 & 1.11 & 0.00 \\
\hline Independent & 4.37 & 3.26 & 1.11 & 0.00 \\
\hline Personal Success & 4.31 & 3.44 & 0.87 & 0.00 \\
\hline Time Management & 4.65 & 3.46 & 1.19 & 0.00 \\
\hline Life Learning & 4.76 & 3.76 & 1.00 & 0.00 \\
\hline Flexibility & 4.37 & 3.57 & 0.80 & 0.00 \\
\hline Negotiation & 4.26 & 3.00 & 1.26 & 0.00 \\
\hline Company Promotion & 3.80 & 2.87 & 0.93 & 0.00 \\
\hline Group Dynamics & 4.41 & 3.13 & 1.28 & 0.00 \\
\hline Teamwork & 4.63 & 3.59 & 1.04 & 0.00 \\
\hline Credibility & 4.74 & 3.63 & 1.11 & 0.00 \\
\hline Interethnic Culture & 4.37 & 3.83 & 0.54 & 0.01 \\
\hline
\end{tabular}

Source: Survey instrument responses, authorial computation.

Examining perceptions of importance that students and employers put on the technical skills revealed that the greatest discrepancies from technical skills are in relation to accounting software and also in corporate governance, risk management and internal controls as well as finance and financial management (Table 3). In fact, discrepancies are the result of employers putting less importance on accounting software but greater importance of corporate governance, risk management and internal controls. Employers know that students and employeesto-be can easily learn to use the company's software if they have a solid 
Atanasovski, A. - Trpeska, M. - Bozinovska Lazarevska, Z.: Accounting Students' and Employers' Perceptions on Employability Skills in the SEE Country.

theoretical background. On the other hand, employers would like the first-time employees to be within their already gained knowledge fully aware of the principles of corporate governance, risk management and functioning and the significance of internal controls.

\section{Tab. 3 Importance of technical and generic skills - students vs. employers' perceptions}

\begin{tabular}{|c|c|c|c|c|}
\hline & Student & Employer & Diff. & Sig. \\
\hline \multicolumn{5}{|l|}{ Technical Skills } \\
\hline Financial Accounting & 4.53 & 4.54 & -0.01 & 0.96 \\
\hline Management Accounting & 4.37 & 4.31 & 0.05 & 0.74 \\
\hline Auditing & 4.44 & 4.44 & -0.00 & 0.99 \\
\hline Business Law & 4.03 & 4.13 & -0.10 & 0.58 \\
\hline Taxation & 4.41 & 4.15 & 0.26 & 0.11 \\
\hline Finance and Financial Management & 4.31 & 4.02 & 0.29 & $0.09 *$ \\
\hline $\begin{array}{l}\text { Corporate Governance, Risk Management and } \\
\text { Internal Controls }\end{array}$ & 3.88 & 4.26 & -0.38 & $0.04_{* *}$ \\
\hline $\begin{array}{l}\text { Business Environment, Business Strategies and } \\
\text { Management }\end{array}$ & 3.85 & 4.04 & -0.18 & 0.30 \\
\hline Numerical Skills (Math and Stat) & 4.16 & 4.19 & -0.02 & 0.90 \\
\hline MS Office & 4.57 & 4.74 & -0.17 & 0.22 \\
\hline $\begin{array}{l}\text { ICT (information and Communication } \\
\text { Technologies) }\end{array}$ & 4.32 & 4.39 & -0.07 & 0.67 \\
\hline Interdisciplinary of Accounting & 4.13 & 4.22 & -0.09 & 0.55 \\
\hline Accounting Software & 4.63 & 3.50 & 1.13 & $0.00 * *:$ \\
\hline \multicolumn{5}{|l|}{ Generic skills } \\
\hline Analysing Information & 4.40 & 4.59 & -0.20 & 0.15 \\
\hline Decision Making & 4.53 & 4.50 & 0.03 & 0.83 \\
\hline Critical Thinking & 4.34 & 4.61 & -0.27 & $0.06 *$ \\
\hline Problem Solving & 4.71 & 4.54 & 0.17 & 0.19 \\
\hline Creative Thinking & 4.34 & 4.30 & 0.04 & 0.80 \\
\hline Written Communication & 4.46 & 4.44 & 0.01 & 0.94 \\
\hline Oral Communication & 4.59 & 4.72 & -0.13 & 0.28 \\
\hline Effective Listening & 4.43 & 4.65 & -0.22 & $0.08 *$ \\
\hline Presentation Skills & 4.38 & 4.26 & 0.12 & 0.40 \\
\hline Foreign Language & 4.66 & 4.74 & -0.08 & 0.51 \\
\hline Good presentation at Interview & 4.68 & 4.35 & 0.33 & $0.03 * *$ \\
\hline Personal Characteristics & 4.75 & 4.46 & 0.29 & $0.02 * *$ \\
\hline Leadership & 4.57 & 4.13 & 0.44 & $0.01 * * ;$ \\
\hline Self-initiative & 4.31 & 4.54 & -0.23 & $0.07 *$ \\
\hline Ethical & 4.49 & 4.76 & -0.27 & $0.04 * *$ \\
\hline
\end{tabular}




\begin{tabular}{lrrrr}
\hline & Student & Employer & Diff. & Sig. \\
\hline Generic skills & & & & \\
\hline Independent & 4.31 & 4.37 & -0.06 & 0.69 \\
Personal Success & 4.59 & 4.31 & 0.27 & $0.05 * *$ \\
Time Management & 4.68 & 4.65 & 0.03 & 0.82 \\
Life Learning & 4.43 & 4.76 & -0.33 & $0.01 * * *$ \\
Flexibility & 4.47 & 4.37 & 0.10 & 0.47 \\
Negotiation & 4.44 & 4.26 & 0.18 & 0.24 \\
Company Promotion & 4.19 & 3.80 & 0.40 & $0.03 * *$ \\
Group Dynamics & 4.07 & 4.41 & -0.33 & $0.02 * *$ \\
Teamwork & 4.66 & 4.63 & 0.03 & 0.81 \\
Credibility & 4.62 & 4.74 & -0.12 & 0.34 \\
Interethnic Culture & 4.46 & 4.37 & 0.09 & 0.62 \\
\hline
\end{tabular}

Source: Survey instrument responses, authorial computation.

Note: $* * * \mathrm{p} \leq 0.01 ; * * \mathrm{p} \leq 0.05 ; * \mathrm{p} \leq 0.1$.

The greatest gaps in ranking of importance of generic skills between students and employers were for leadership and life-long learning, where students put greater importance on leadership and employers on life-long learning. This is expected, since employers view students more as a part of the team instead of immediate leaders following their graduation, unlike students who are fully motivated and enthusiastic for their careers. For employers it is far more important to have an ability and desire for life-long learning in order to operate effectively in the dynamic environment. Other discrepancies in the student-employer views in respect of generic skills were in putting greater importance from students on good presentation on the interview, personal characteristics and personal success while employers put greater importance on ethical behaviour and understanding of the group dynamics as well as critical thinking, effective listening and self-initiative (Table 3).

When we compared the perceived acquisition of technical and generic skills through the accounting program at the university, we have concluded that for majority technical and generic skills, both groups of respondents gave similar ratings of achievement. Technical skills related to the use of accounting software and knowledge in taxation and business law were given the lowest ratings of achievement. From the group of generic skills, marketing and company promotion skills as well as creative thinking were considered as least achieved through the accounting program. However, employers in comparison to students perceived significantly lower the possessed technical knowledge in financial and management accounting, finance and financial management and numerical skills among successful graduates of the accounting program. In terms of generic skills, 
employers were considerably less satisfied than students with the acquired oral communication, effective listening and time management skills.

We have tried to identify factors and characteristics of the group of surveyed students that could explain the discrepancy in their views against employers for the importance and possession of relevant knowledge and skills. We have considered and analysed separately responses from high-performing students visà-vis below-average students and employers and found that results were not substantially different. Therefore, the success in the education program was not a factor that could explain discrepancies in perceptions. We also paid attention to differences in responses between students that identified possession of relevant or irrelevant practical experience and concluded that there were no significant differences in responses.

\section{Conclusion}

A number of research studies, policy papers and reports in the past, both in Europe and internationally, have expressed concerns about the need to develop more transferable generic skills among university graduates in order to improve their employability and enable sustainable development in societies. In this study, we have determined a list of 39 technical and generic skills through mapping and comparing higher education curricula development frameworks, international education standards for professional accounting education, and various international research studies of accounting education. The study focused on skills and knowledge sets considered important for the accounting-related workplace by two interested groups for accounting education, accounting students and employers. We have also investigated the success of an undergraduate accounting education program from a local university in Macedonia to develop generic and technical skills sufficient to the level of perceived importance of these skills.

The results of the study indicated that employers and students were in agreement in terms of ranking higher importance of generic skills than technical skills for better employability in accounting workplaces. However, students perceived personal skills of time management and personal characteristics of self-confidence and motivation as the most important, while employers gave more importance to oral communication, ethical attitude and credibility and commitment to life-long learning. For technical skills, both students and employers considered experience with the MS Office package as very important, but they were in disagreement regarding the high importance of accounting software skills, as these were perceived more important by the student respondents.

In respect of successfulness of the university undergraduate accounting program to develop relevant knowledge and skills for employability, both students and employers viewed knowledge in the areas of taxation and business law and skills 
with accounting software as significantly underdeveloped to the expected level of importance for their employment. Comparing views of students and employers in terms of generic skills developed through the undergraduate education program in accounting, employers consistently rated generic skills with greater discrepancy between skills' importance level and skills' possession level among graduates of the program.

The study contributes to the literature of investigative studies on employability skills for accounting graduates through the extended surveyed list of skills and knowledge sets that considered both the professional and academic education benchmark standards as well as skills identified relevant in past research studies. Considering the identified discrepancy between perceived importance and possession of certain knowledge and skills among graduates, future research into views and perceptions of academics could provide indications of gaps whose resolution could improve the quality of the education program and process for the benefit of graduates' employability and work readiness.

\section{References}

Albrecht, W. S., Sack, R. J., 2000. Accounting Education: Charting the Course Through a Perilous Future. American Accounting Association, Lakewood Ranch.

American Institute of Certified Public Accountants (AICPA), 1998. CPA Vision Project: focus on the Horizon, Executive summary and CPA Vision Project Focus Groups: Public Practice. Industry and Government CPAs, New York.

Andrews, J., Higson, H., 2008. Graduate Employability, 'Soft Skills' Versus 'Hard' Business Knowledge: A European Study. Higher Education in Europe 33, 411-422. DOI: 10.1080/03797720802522627.

Bui, B., Porter, B., 2010. The Expectation-Performance Gap in Accounting Education: An Exploratory Study. Accounting Education 19, 23-50. DOI: 10.1080/09639280902875556.

Bunney, D., Sharplin, E., Howitt, C., 2015. Generic skills for graduate accountants: the bigger picture, a social and economic imperative in the new knowledge economy. Higher Education Research \& Development 34, 256-269. DOI: 10.1080/07294360.2014.956700.

Crawford, L., Helliar, C., Monk, E. A., 2011. Generic Skills in Audit Education. Accounting Education 20, 115-131. DOI: 10.1080/09639284.2011.557487.

De Lange, P., Jackling, B., Gut, A. M., 2006. Accounting graduates' perceptions of skills emphasis in undergraduate courses: an investigation from two Victorian universities. Accounting and Finance 46, 365-386. DOI: 10.1111/j.1467629X.2006.00173.x. 
Atanasovski, A. - Trpeska, M. - Bozinovska Lazarevska, Z.: Accounting Students' and Employers' Perceptions on Employability Skills in the SEE Country.

Gabbin, A. L., 2002. The Crisis in Accounting Education. Journal of Accountancy 4, 81-86.

Gammie, B., Gammie, E., Cargill, E., 2002. Personal skills development in the accounting curriculum. Accounting Education 11, 63-78. DOI: 10.1080/09639280210153272.

Hassall, T., Joyce, J., Montano, J. L. A., Anes, J. A. D., 2003. The vocational skills gap for management accountants: the stakeholders' perspectives. Innovations in Education and Teaching International 40, 78-88. DOI: $10.1080 / 1355800032000038796$.

Howieson, B., 2003. Accounting practice in the new millennium: is accounting education ready to meet the challenge? The British Accounting Review 35, 69103. DOI: $10.1016 / \mathrm{S} 0890-8389(03) 00004-0$.

Institute of Chartered Accountants in Australia (ICAA), 2001. The New CFO of the Future: Finance Functions in the Twenty-first Century, prepared by M. Simister for KPMG Consulting for the ICAA (Sydney: ICAA).

Jackling, B., De Lange, P., 2009. Do Accounting Graduates' Skills Meet the Expectations of Employers? A Matter of Convergence or Divergence. Accounting Education 18, 369-385. DOI: 10.1080/09639280902719341.

Jones, R., 2014. Bridging the Gap: Engaging in Scholarship with Accountancy Employers to Enhance Understanding of Skills Development and Employability. Accounting Education 23, 527-541. DOI: 10.1080/09639284.2014.965959.

Kavanagh, M. H., Drennan, L., 2008. What skills and attributes does an accounting graduate need? Evidence from student perceptions and employer expectations. Accounting \& Finance 48, 279-300. DOI: 10.1111/j.1467629X.2007.00245.X.

Leveson, L., 2000. Disparities in perceptions of generic skills: Academics and employers. Industry and Higher Education 14, 157-164. DOI: 10.5367/000000000101295002.

Mohamed, E. K. A., Lashine, S. H., 2003. Accounting knowledge and skills and the challenges of a global business environment. Managerial Finance 29, 3-16. DOI: $10.1108 / 03074350310768319$.

Quality Assurance Agency for Higher Education, 2016. Subject benchmark statement - Accounting (QAA for Higher Education). Available from: <http://www.qaa.ac.uk/en/Publications/Documents/SBS-Accounting-16.pdf >. [12 March 2018].

Tempone, I., Kavanagh, M., Segal, N., Hancock, P., Howieson, B., Kent, J., 2012. Desirable generic attributes for accounting graduates into the twenty-first century: 
The views of employers. Accounting Research Journal 25, 41-55. DOI: 10.1108/10309611211244519.

Webb, J., Chaffer, C., 2016. The expectation performance gap in accounting education: a review of generic skills development in UK accounting degrees. Accounting Education 25, 349-367. DOI: 10.1080/09639284.2016.1191274.

Wells, P., Gerbic, P., Kranenburg, I., Bygrave, J., 2009. Professional Skills and Capabilities of Accounting Graduates: The New Zealand Expectation Gap? Accounting Education 18, 403-420. DOI: 10.1080/09639280902719390.

Yu, S. C., Churyk, N. T., 2013. Are students ready for their future accounting careers? Insights from observed perception gaps among employers, interns, and alumni. Global Perspectives on Accounting Education 10. 
